\title{
The cholesterol derivative 27-hydroxycholesterol reduces steatohepatitis in mice.
}

Citation for published version (APA):

Bieghs, V., Hendrikx, T., van Gorp, P. J. J., Verheyen, F., Guichot, Y. D., Walenbergh, S. M., Gijbels, M. J. J., Rensen, S. S. M., Bast, A., Plat, J., Kalhan, S. C., Leitersdorf, E., Hofker, M. H., Lutjohann, D., \& Shiri-Sverdlov, R. (2013). The cholesterol derivative 27-hydroxycholesterol reduces steatohepatitis in mice. Gastroenterology, 144(1), 167-178.e1. https://doi.org/10.1053/j.gastro.2012.09.062

Document status and date:

Published: 01/01/2013

DOI:

10.1053/j.gastro.2012.09.062

Document Version:

Publisher's PDF, also known as Version of record

Document license:

Taverne

Please check the document version of this publication:

- A submitted manuscript is the version of the article upon submission and before peer-review. There can be important differences between the submitted version and the official published version of record.

People interested in the research are advised to contact the author for the final version of the publication, or visit the DOI to the publisher's website.

- The final author version and the galley proof are versions of the publication after peer review.

- The final published version features the final layout of the paper including the volume, issue and page numbers.

Link to publication

\footnotetext{
General rights rights.

- You may freely distribute the URL identifying the publication in the public portal. please follow below link for the End User Agreement:

www.umlib.nl/taverne-license

Take down policy

If you believe that this document breaches copyright please contact us at:

repository@maastrichtuniversity.nl

providing details and we will investigate your claim.
}

Copyright and moral rights for the publications made accessible in the public portal are retained by the authors and/or other copyright owners and it is a condition of accessing publications that users recognise and abide by the legal requirements associated with these

- Users may download and print one copy of any publication from the public portal for the purpose of private study or research.

- You may not further distribute the material or use it for any profit-making activity or commercial gain

If the publication is distributed under the terms of Article $25 \mathrm{fa}$ of the Dutch Copyright Act, indicated by the "Taverne" license above, 


\title{
BASIC AND TRANSLATIONAL一LIVER
}

\section{The Cholesterol Derivative 27-Hydroxycholesterol Reduces Steatohepatitis in Mice}

\author{
VEERLE BIEGHS, ${ }^{1,2}$ TIM HENDRIKX, ${ }^{1}$ PATRICK J. VAN GORP, ${ }^{1}$ FONS VERHEYEN, ${ }^{3}$ YASMIN DIAS GUICHOT, ${ }^{1}$ \\ SOFIE M. A. WALENBERGH, ${ }^{1}$ MIKE L. J. JEURISSEN, ${ }^{1}$ MARION GIJBELS, ${ }^{1}$ SANDER S. RENSEN, ${ }^{4}$ AALT BAST, ${ }^{5}$ \\ JOGCHUM PLAT, ${ }^{6}$ SATISH C. KALHAN, ${ }^{7}$ GER H. KOEK, ${ }^{8}$ ERAN LEITERSDORF, ${ }^{9}$ MARTEN H. HOFKER, ${ }^{10}$ \\ DIETER LÜTJOHANN, ${ }^{11}$ and RONIT SHIRI-SVERDLOV ${ }^{1}$
}

\begin{abstract}
${ }^{1}$ Department of Molecular Genetics, Maastricht University, Maastricht, the Netherlands; ${ }^{2}$ Department of Internal Medicine III, RWTH-University Hospital Aachen, Aachen, Germany; ${ }^{3}$ Department of Electron Microscopy, ${ }^{4}$ Department of General Surgery, ${ }^{5}$ Department of Toxicology, ${ }^{6}$ Department of Human Biology, Maastricht University, Maastricht, the Netherlands, ${ }^{7}$ Department of Pathobiology, Lerner Research Institute, The Cleveland Clinic Foundation, Cleveland, Ohio; ${ }^{8}$ Department of Internal Medicine, Section of Gastroenterology/Hepatology, Maastricht University Medical Center, the Netherlands; ${ }^{9}$ Department of Medicine, Hadassah-Hebrew University Medical Center, Jerusalem, Israel; ${ }^{10}$ Department of Pathology \& Laboratory Medicine, University Medical Center Groningen, University of Groningen, Groningen, the Netherlands; and ${ }^{11}$ Institute of Clinical Chemistry and Clinical Pharmacology, University of Bonn, Bonn, Germany
\end{abstract}

BACKGROUND \& AIMS: Non-alcoholic steatohepatitis is characterized by hepatic steatosis with inflammation. Although steatosis is benign and reversible, inflammation can increase liver damage. Hepatic inflammation has been associated with accumulation of cholesterol in lysosomes of Kupffer cells. 27Hydroxycholesterol (27HC), a derivative of cholesterol formed by CYP27A1, can mobilize cholesterol from the lysosomes to the cytoplasm. We investigated whether $27 \mathrm{HC}$ can change the intracellular distribution cholesterol and reduce hepatic inflammation in mice. METHODS: We transplanted bone marrow from irradiated wild-type or Cyp27a1 $1^{-/-}$mice to mice that do not express the low density lipoprotein receptor $\left(\mathrm{Ldll}^{-/-}\right)$, which are hyperlipidemic; 9 weeks later, mice were fed either regular chow or a high-fat, high-cholesterol (HFC) diet for 3 months. In a separate experiment, $\mathrm{Ldlr}^{-/}$mice were given subcutaneous injections of 27HC and placed on regular chow or HFC diets for 3 weeks. Blood and liver tissues samples were collected and analyzed for intracellular cholesterol distribution and inflammation. RESULTS: In $\mathrm{Ldlr}^{-/-}$mice that received bone marrow transplants from Cyp27a1 $1^{-/}$mice, lysosomes of Kupfer cells had a greater accumulation of cholesterol than those of mice that received bone marrow from wild-type mice, after the HFC diet. Liver histology and gene expression analyses showed increased inflammation and liver damage in mice given bone marrow transplants from $\mathrm{Cyp} 27 \mathrm{a} 1^{-/-}$mice and placed on the HFC diet. Administration of $27 \mathrm{HC}$ to $\mathrm{Ldlr}^{-/-}$mice, following the HFC diet, reduced the accumulation of lysosomal cholesterol and hepatic inflammation, compared with mice that were not given 27HC. CONCLUSIONS: Accumulation of cholesterol in lysosomes of Kupfer cells promotes hepatic inflammation in mice. The cholesterol derivative $27 \mathrm{HC}$ reduces accumulation of cholesterol in lysosomes and might be used to treat non-alcoholic steatohepatitis.

Keywords: Metabolic Syndrome; Fatty Liver; NAFLD; Mouse Model.

$\mathrm{N}$ on-alcoholic fatty liver disease (NAFLD) is the hepatic component of metabolic syndrome, a cluster of risk factors that contribute to the development of type 2 diabetes and cardiovascular disease. Non-alcoholic steatohepatitis (NASH) is considered to be the most severe form of NAFLD and is characterized by fat accumulation in the liver (steatosis) and hepatic inflammation. Whereas steatosis itself is generally considered a rather benign and reversible condition, the presence of inflammation in a fatty liver is the key feature of NASH that precedes further disease progression and enables the development of more advanced stages of the disease, such as fibrosis, cirrhosis, or hepatocellular carcinoma, often leading to the need for liver transplantation. ${ }^{1}$ Knowledge of the intracellular mechanisms that trigger inflammation during NASH is therefore of utmost importance.

Various mechanisms have been proposed for the intracellular triggering of inflammation. In mice lacking the low-density lipoprotein receptor $\left(\mathrm{Ldlr}^{-/}\right)$, we have previously shown that hematopoietic deletion of the 2 main scavenger receptors (CD36 and scavenger receptor A), which are responsible for the uptake of modified lipoproteins, sets off a cascade of proinflammatory events leading to the initiation of the inflammatory response in the liver. ${ }^{2}$ Moreover, the reduced inflammatory response was associated with less lysosomal cholesterol accumulation inside Kupffer cells (KCs). ${ }^{3,4}$ However, a causal link between lysosomal cholesterol accumulation in KCs and hepatic inflammation has not yet been established.

Under normal conditions, lipoproteins circulating in the blood will be endocytosed by macrophages and initially directed to lysosomes, where the lipoproteins are hydrolyzed by lysosomal enzymes and transferred into the

Abbreviations used in this paper: 27HC, 27-hydroxycholesterol (25(R)26 hydroxycholesterol); ALT, alanine aminotransferases; COL1A1, collagenase 1A1; CTX, cerebrotendinous xanthomatosis; HFC, high-fat high cholesterol; IL, interleukin; KC, Kupffer cell; LAL, Iysosomal acid lipase; Ldlr, low-density lipoprotein receptor; LXR, liver-X receptor; Mcp-1, monocyte chemoattractant protein 1; NAFLD, non-alcoholic fatty liver disease; NASH, non-alcoholic steatohepatitis; NPC, Niemann-Pick type C; TG, trig lycerides; TNF, tumor necrosis factor; tp, transplanted; Wt, wild type.

(C) 2013 by the AGA Institute 0016-5085/\$36.00

http://dx.doi.org/10.1053/j.gastro.2012.09.062 
cytoplasm. ${ }^{5}$ However, in foamy macrophages of inflamed atherosclerotic plaques, cholesterol is not transferred into the cytoplasm but rather accumulates in the lysosomes of the macrophages. ${ }^{6}$ Accumulation of cholesterol inside lysosomes is also a key feature of Niemann-Pick disease type C (NPC1), a lipid storage disease resulting from a deletion in the NPC1 gene, which encodes a key protein involved in the translocation of cholesterol from the lysosomes to the cytoplasm. NPC1 deficient cells have a severely reduced production of 27-hydroxycholesterol (27HC), one of the major oxysterols found in the human circulation, which is produced by the mitochondrial enzyme CYP27A1. Notably, the lysosomal cholesterol pool in $\mathrm{NPC1}^{-/-}$fibroblasts is dramatically reduced upon incubation with $27 \mathrm{HC}^{7,8}$ Thus, $27 \mathrm{HC}$ has been shown to reduce lysosomal cholesterol accumulation in vitro.

The aim of the current study was to investigate whether the mobilization of cholesterol inside the KCs from the lysosomes to the cytoplasm can reduce hepatic inflammation in vivo. We injected bone marrow cells from Cyp27a1 $1^{-/-}$mice into lethally irradiated $\mathrm{Ldlr}^{-/-}$hyperlipidemic host mice to generate bone marrow chimeras with decreased production of $27 \mathrm{HC}$ specifically in hematopoietic cells. We hypothesized that this decreased production of $27 \mathrm{HC}$ by KCs would inhibit the translocation of cholesterol from the lysosomes to the cytoplasm and thereby increase hepatic inflammation. In agreement with our hypothesis, we indeed demonstrated that mice trans-

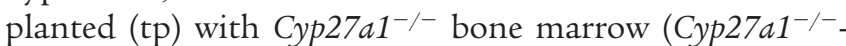
tp) showed higher lysosomal cholesterol accumulation in KCs than mice transplanted with bone marrow from wild-type (Wt) C57Bl/6. In addition, the increased lysosomal cholesterol accumulation in these mice was associated with increased inflammation and liver damage. Next, to examine whether exogenous administration of $27 \mathrm{HC}$ (25(R)26-hydroxycholesterol) would decrease inflammation, $\mathrm{Ldll}^{-/-}$mice were injected with $27 \mathrm{HC}$. These mice had reduced lysosomal cholesterol accumulation, which was associated with far less hepatic inflammation than in control injected $\mathrm{Ldlr}^{-/-}$mice. Altogether, these data support a causal role for lysosomal cholesterol accumulation in hepatic inflammation and highlight the potential of using $27 \mathrm{HC}$ as a novel treatment for NASH.

\section{Materials and Methods}

\section{Mice, Diet, and Bone Marrow Transplantation}

Mice were housed under standard conditions and given free access to food and water. Experiments were performed according to Dutch regulations and approved by the Committee for Animal Welfare of Maastricht University. In the first study, 12-week-old female $\mathrm{Ldlr}^{-/-}$mice were lethally irradiated and transplanted with Wt or Cyp27a1-/- bone marrow as previously described. ${ }^{2}$ After a recovery period of 9 weeks, the mice were given either chow or HFC diet for 3 months (chow: $\mathrm{n}=5$; HFC: $\mathrm{n}=10)$. In the second experiment, the effects of $27 \mathrm{HC}(25(\mathrm{R}) 26$ hydroxycholesterol) on NASH were investigated in female $\mathrm{Ldlr}^{-/-}$mice by means of daily subcutaneous injections with 40 mg per kg of body weight of $27 \mathrm{HC}$ for 3 weeks. Two-hydroxypropyl- $\beta$-cyclodextrin (H5784; Sigma-Aldrich $\mathrm{GmbH}$, Zwijndrecht, the Netherlands) was used as a vehicle to dissolve $27 \mathrm{HC}$, as described by De Caprio et al. ${ }^{9}$ Two-hydroxypropyl- $\beta$-cyclodextrin was also used for the control injections. The mice were given chow or HFC diet for 3 weeks ( $\mathrm{n}=9$ for all groups). To investigate the therapeutic effect of $27 \mathrm{HC}$, one group of $\mathrm{Ldlr}^{-/-}$ mice on HFC diet received control injections for 2 weeks and injections with $27 \mathrm{HC}$ in the third week $(\mathrm{n}=9)$. In the chow diet, no evidence for $27 \mathrm{HC}$ was found (or it was below the detection limit). In the HFC diet, $27 \mathrm{HC}$ reached a concentration of 1.428 $\mathrm{ng} / \mathrm{mg}$. The HFC diet contained $21 \%$ milk butter, $0.2 \%$ cholesterol, $46 \%$ carbohydrates, and $17 \%$ casein. Collection of blood and tissue specimens, biochemical determination of lipids in plasma and liver, liver histology, electron microscopy, RNA isolation, complementary DNA synthesis and quantitative polymerase chain reaction, aminotransferases, and oxysterols were determined as described previously. ${ }^{2-4,10,11}$ Information about the obese NASH subjects, the $\mathrm{KC}$ isolation, the cathepsin $\mathrm{D}$ activity assay, the malondialdehyde assay, the antioxidant capacity assay, and the statistical analysis are described extensively in Supplementary Materials and Methods.

\section{Results}

\section{Steatosis Is Not Affected by Hematopoietic Deletion of Cyp27a1, Whereas Plasma Lipid Levels Are Significantly Reduced}

The role of CYP27A1 in diet-induced NASH was investigated by transplanting Cyp27a1 $1^{+/+}$(Wt) and Cyp27a1 $1^{-/-}$bone marrow into $L d l r^{-/-}$mice. After a recovery period of 9 weeks, mice received chow or HFC diet for 3 months. Body weight did not differ significantly between groups (data not shown). After 3 months of HFC diet, equal levels of steatosis developed in the 2 transplanted groups. Neither hepatic triglyceride (TG) levels nor hepatic cholesterol differed between the groups (Table 1). Additionally, Oil Red $O$ staining showed no difference in the levels of liver lipids in Wt-tp and Cyp27a1-/- tp mice upon HFC diet (Supplementary Figure 1). When comparing chow and HFC fed mice, hepatic 27HC/cholesterol levels were decreased upon HFC feeding (Wt-tp chow vs HFC diet: $P<.0001 ; C y p 27 a 1^{-/-}$-tp chow vs HFC diet: $P<.0001)$, although there were no differences between Wt-tp and Cyp27a1 $1^{-/-}$-tp mice (Table 1). In general, both groups developed equal levels of hepatic steatosis.

In mice on an HFC diet, plasma lipid levels were increased, whereas total cholesterol $(P=.0014)$ as well as TG $(P=$ .0004) levels were significantly lower in Cyp27a1 ${ }^{-/-}$-tp mice than in their controls (Table 1). In addition, the levels of 27HC in plasma were lower in Cyp27a1 ${ }^{-/-}$-tp mice than in Wt-tp mice $(P=.048)$. There were no differences between the groups of mice fed a chow diet (Table 1).

\section{CYP27A1 Influences the Foamy Appearance and Lysosomal Cholesterol Storage of $\mathrm{KC}$}

To determine whether there was a difference in the foamy appearance of KCs, liver sections were stained for CD68, a macrophage marker that stains KCs. After dietary intervention, CD68-positive cells were swollen and in- 
Table 1. Liver and Plasma Lipid Levels: Wt-tp and Cyp27a1-/--tp Mice

\begin{tabular}{|c|c|c|c|c|}
\hline & \multicolumn{2}{|c|}{ Chow } & \multicolumn{2}{|c|}{$\mathrm{HFC}$} \\
\hline & Wt-tp & Сур27-/--tp & Wt-tp & Сyp27-/--tp \\
\hline \multicolumn{5}{|l|}{ Liver } \\
\hline 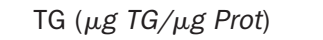 & $0.21( \pm 0.032)$ & $0.15( \pm 0.024)$ & $0.50( \pm 0.074)$ & $0.49( \pm 0.072)$ \\
\hline 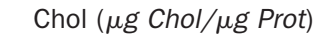 & $0.090( \pm 0.017)$ & $0.087( \pm 0.0049)$ & $0.26( \pm 0.024)$ & $0.26( \pm 0.033)$ \\
\hline $27 \mathrm{HC} / \mathrm{Chol}$ & $0.46( \pm 0.082)$ & $0.51( \pm 0.10)$ & $0.15( \pm 0.026)$ & $0.13( \pm 0.022)$ \\
\hline \multicolumn{5}{|l|}{ Plasma } \\
\hline $\mathrm{TG}(\mathrm{mmol} / \mathrm{L})$ & $0.46( \pm 0.093)$ & $0.42( \pm 0.086)$ & $1.7( \pm 0.50)$ & $0.79( \pm 0.24)^{a}$ \\
\hline Chol $(\mathrm{mmol} / \mathrm{L})$ & $6.79( \pm 0.31)$ & $6.39( \pm 0.54)$ & $36.71( \pm 1.65)$ & $22.48( \pm 2.62)^{b}$ \\
\hline $27 \mathrm{HC} / \mathrm{Chol}\left(* 10^{-3}\right)$ & $0.047( \pm 0.00061)$ & $0.046( \pm 0.00071)$ & $0.051( \pm 0.0041)$ & $0.045( \pm 0.0057)^{c}$ \\
\hline
\end{tabular}

NOTE. Liver and plasma triglycerides, cholesterol, and 27HC levels after chow and HFC diet.

Chol, cholesterol; Prot, protein; TG, triglycerides.

ap $<.001$.

${ }^{b} P<.01$

${ }^{c} P<.05$.

creased in size, resembling the aggregation of lipoproteins in foamy macrophages during atherosclerotic lesion development. This foamy phenotype of KCs is similar to previous studies performed when $\mathrm{Ldlr}^{-/}$mice are fed a HFC diet. ${ }^{10,12}$ Of note, the increased size was correlated with the increased lipid content within these cells. The comparison of CD68-positive cells revealed a clear difference between the KCs of the Cyp27a1 $1^{-1-}$-tp and Wt-tp mice. The KCs of Wt-tp mice on the HFC diet were extremely foamy, whereas the KCs of Cyp2a17-/were much less foamy after 3 months on the HFC diet (Figure 1A). These data were also confirmed by gene expression analysis of $C d 68(P=.015)$, which demonstrated reduced expression of this macrophage marker in the livers of mice with hematopoietic deletion of Cyp27a1 (Figure 1B). These data suggest that Cyp27a1 $1^{-/}$-tp mice on HFC diet have altered hepatic cholesterol metabolism.

Next, electron microscopy was performed to explore the intracellular cholesterol distribution inside KCs. As demonstrated in Figure 1, Wt-tp mice on HFC diet had more lipid droplets inside KCs than the Cyp27a1 $11^{-/-}$-tp mice. Although

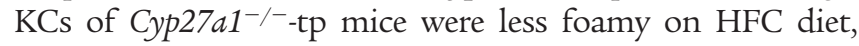
these KCs had more lysosomal cholesterol accumulation than Wt-tp mice, as indicated by the lysosomal acid phosphatase staining (Figure 1D). Acid phosphatase staining also showed that a large amount of lipids was present outside the lysosomes in the KCs of the Wt-tp mice. We also saw more abnormal lipid structures resembling cholesterol precipitations in the KCs of Cyp27a1 $1^{-/-}$tp mice than in those of Wt-tp mice. The changes in intracellular lipid distribution in Cyp27a1 $1^{-/-}$-tp mice were accompanied by higher hepatic levels of the lysosomal enzyme cathepsin $\mathrm{D}(P=.031)$ than in Wt-tp mice on the HFC diet (Figure 1C). Altogether, these data demonstrate disturbed lysosomal storage in KCs of Cyp27a1-/- -tp mice.

\section{Increased Liver $X$ Receptor Expression in Cyp27a1-/--tp Mice}

To investigate the effect of the Cyp27a1 deletion on cellular cholesterol homeostasis, gene expression of the nuclear receptor Liver $\mathrm{X}$ receptor $(L x r)$ and its down- stream target genes sterol regulatory element binding protein 1c (Srebp-1c), adenosine triphosphate-binding cassette transporter A1 (Abca1), and G1 (Abcg1) was analyzed in total liver. The expression of $\operatorname{Lxr}-\alpha(P=.037)$, together with the target genes Srebp-1c $(P=.033), \operatorname{Abca1}(P=.012)$,

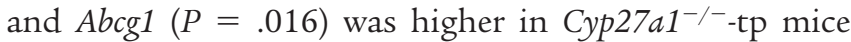
than in Wt-tp mice upon HFC diet (Supplementary Figure 2). These data indicate that LXR is more active in Cyp27a1 $11^{-/-}$-tp mice than in Wt-tp mice.

\section{Cyp27a1-/--tp Mice Demonstrate Increased Hepatic Inflammation and Liver Damage}

To investigate the effect of hematopoietic deletion of Cyp27a1 on hepatic inflammation, liver sections were stained with antibodies against several inflammatory markers. This revealed a significantly higher level of in-

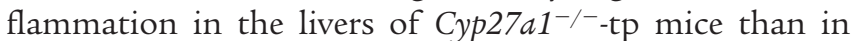
those of Wt-tp mice (Figure $2 A$ ), as indicated by the higher numbers of infiltrating macrophages $(P=.0039)$, neutrophils $(P=.031)$, and $\mathrm{T}$ cells $(P=.010)$ in these mice. Moreover, Mac-1-positive cells were more clustered in Cyp27a1 ${ }^{-/-}$-tp mice than in Wt-tp mice (Figure 2B). To define further the differences in hepatic inflammation, we analyzed gene expression of the proinflammatory cytokines tumor necrosis factor (Tnf), monocyte chemoattractant protein $1(M c p-1)$, interleukin $1 \beta(I l-1 \beta)$, and $I l-6$, which are known to be elevated in NASH patients and animals and to activate nuclear factor- $\kappa \mathrm{B}$ signaling and acute phase protein production in the liver..$^{13,14}$ As shown in Figure 2C, gene expression of $\operatorname{Tnf}(P=.043), \operatorname{Mcp}-1(P=$ $.050), \mathrm{Il}-1 \beta(P=.037)$, and Il-6 $(P=.0034)$ was significantly higher in Cyp27a1 $1^{-1-}$-tp mice than in Wt-tp mice on the HFC diet, confirming the histologic data.

To explore the role of CYP27 on oxidative stress, the lipid peroxidation marker malondialdehyde and the antioxidant marker Trolox Equivalent Antioxidant Capacity were measured in livers of Wt- and Cyp27a1-/- tp mice. These data indicate that the level of oxidative stress was not affected in both Wt- and Cyp27a1 ${ }^{-/-}$-tp mice (Supplementary Figure $3 A$ ). In addition, hepatic expression levels of several anti- and pro-oxidant genes such as Catalase, 

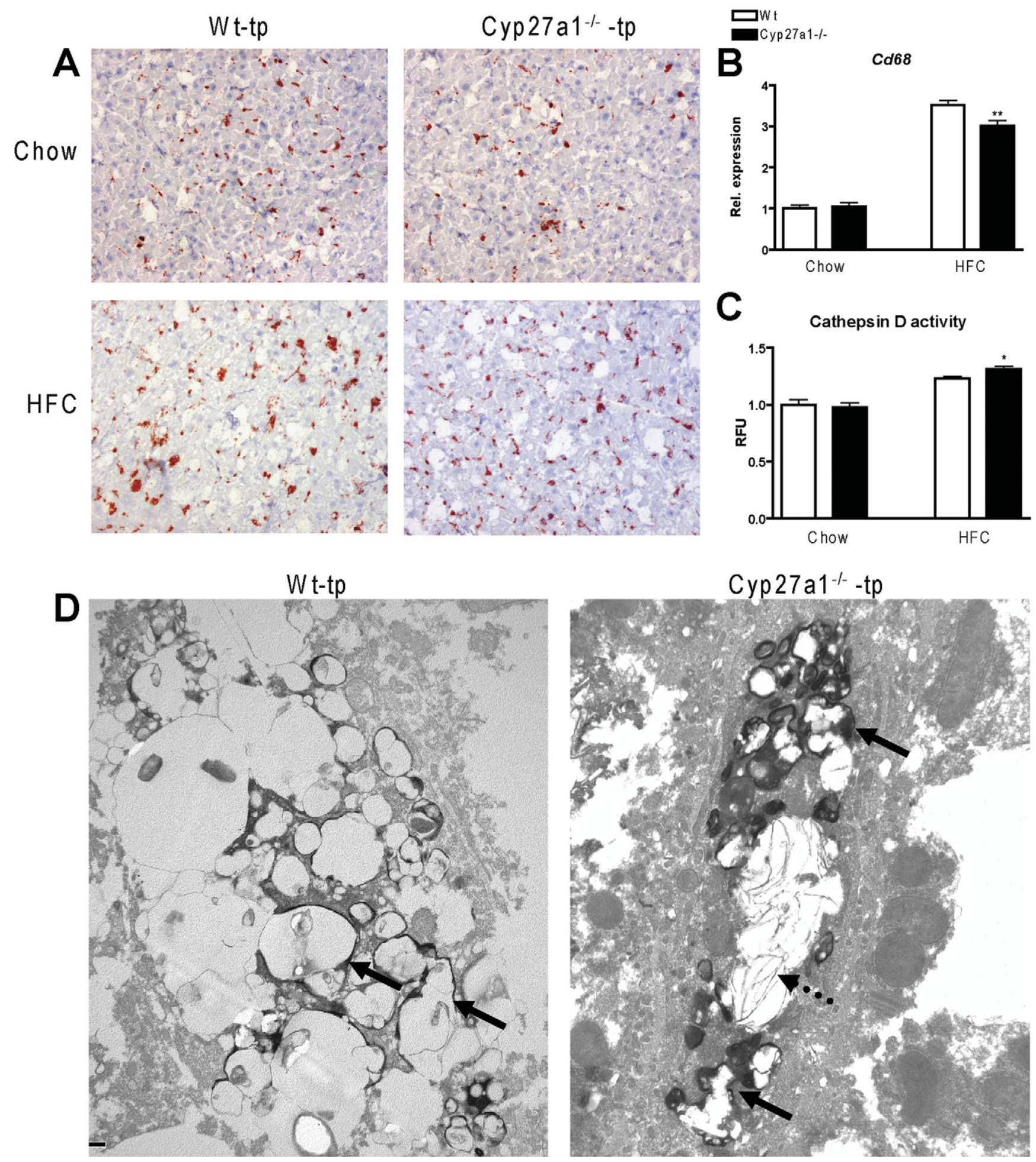

Figure 1. Foamy Kupffer cells in Wt-tp and Cyp27a1-1--tp mice. (A) Representative pictures of CD68 staining (original magnification, 200X) after 3 months of chow or HFC diet. (B) Gene expression of the macrophage marker Cd68. (C) Hepatic activity of the lysosomal enzyme Cathepsin D. (D) Representative electron microscopy pictures of KCs after 3 months of HFC diet. Lysosomes are indicated in black by acid phosphatase staining (solid arrows). Abnormal lipid structures resembling cholesterol precipitations are indicated by the broken arrows. ${ }^{*}$ ndicates $P<.05$ and ${ }^{* \star} P<.01$.

superoxide dismutase 2 (Sod-2), heme oxygenase (Hmox), glutathione s-transferase (Gst), cytochrome P450 2E1 (Cyp2E1), and C/EBP homologous protein (Chop) confirmed that there were no significant differences in oxidative stress between Wt- and Cyp27a1 ${ }^{-/-}$-tp mice (Supplementary Figure $3 B$ ).
Elevated alanine aminotransferase (ALT) levels in plasma are considered to be sensitive indicators of liver damage. After 3 months of HFC diet, plasma ALT levels were higher in Cyp27a1-/- $\mathrm{tp}$ mice than in Wt-tp mice $(P=.048)$ (Figure $3 A)$. In line with these findings, hepatic fibrosis was also higher in Cyp27a1 $1^{-/-}$-tp mice than in 
A

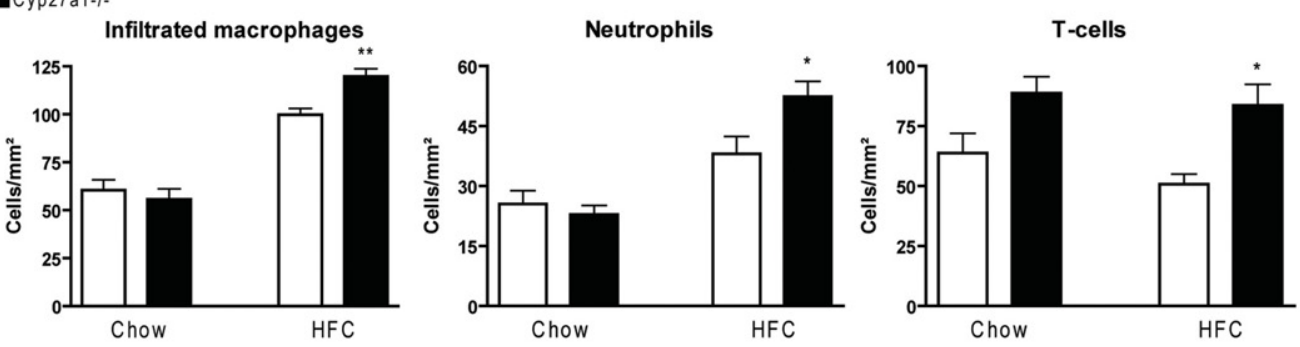

B
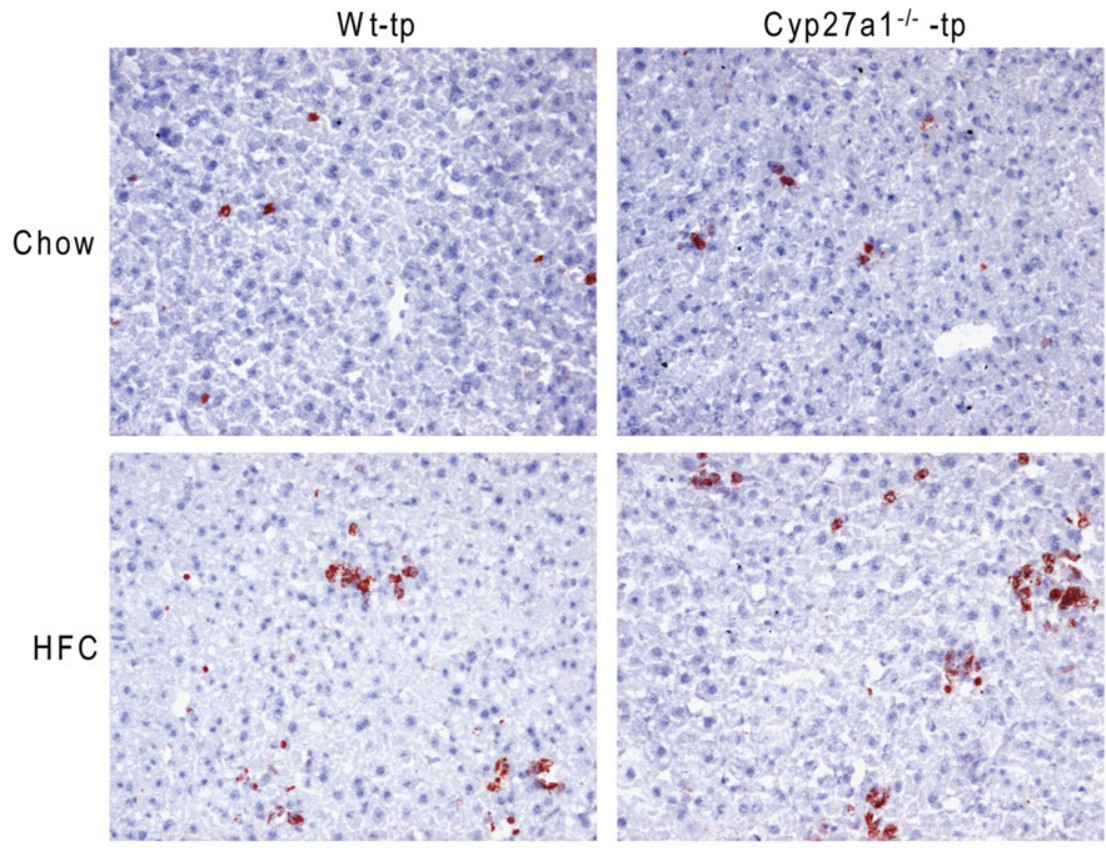

C
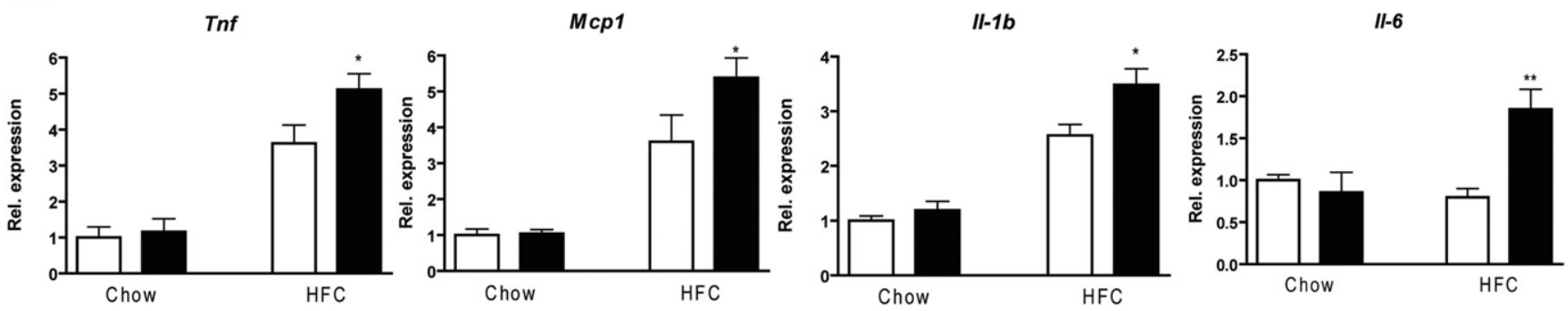

Figure 2. Parameters of hepatic inflammation in Wt-tp and Cyp27a1-1--tp mice. (A) Liver sections were stained for infiltrating macrophages, neutrophils, and T cells and the positive cells counted. (B) Representative pictures of Mac-1 staining (original magnification, 200X) after 3 months of HFC diet. (C) Gene expression analysis of Tnf, Mcp-1, II-1 $\beta$, and II-6. Gene expression data are shown relative to Wt-tp mice on chow diet. *Indicates $P<.05$ and ${ }^{* \star} P<.01$.

Wt-tp mice, as demonstrated by collagen staining with Sirius Red and gene expression analysis (Figure $3 B-E$ ). Although fibrosis was moderate, Cyp27a1 ${ }^{-/-}$-tp mice had increased collagen content upon HFC diet than the Wt-tp mice (Figure $3 B$ and $C$ ). After 3 months of HFC diet, hepatic gene expression of transforming growth factor $\beta$ $($ Tgf $-\beta)(P=.044)$, metalloproteinase $9(M m p-9)(P=.050)$, and plasminogen activator inhibitor-1 (Pai-1) $(P=.041)$ was higher in Cyp27a1-/- $t \mathrm{p}$ mice than in Wt-tp mice (Figure $3 D$ ). A similar trend was observed for the expression of collagen 1A1 (Col1a1) after 3 months of HFC diet; however, this did not reach statistical significance $(P=$
$.08)$. Activated hepatic stellate cells could not be observed in Wt- and Cyp27a1 ${ }^{-1-}$-tp mice upon HFC diet, neither by $\alpha$-smooth muscle cell actin ( $\alpha$-SMA) staining nor by gene expression of $\alpha$-Sma (Supplementary Figure 4). Altogether, these data indicate that Cyp27a1 $21^{-/-}$-tp mice are more susceptible to hepatic inflammation and liver damage.

\section{Administration of 27HC Does Not Affect Steatosis but Lowers Plasma Cholesterol Levels}

Next, to investigate whether exogenous administration of $27 \mathrm{HC}$ can reduce inflammation during $\mathrm{NASH}$, $\mathrm{Ldlr}^{-/-}$mice were given daily injections of $27 \mathrm{HC}$ or con- 
A $\square_{\text {cyp27a1-/. }}^{W t}$

ALT

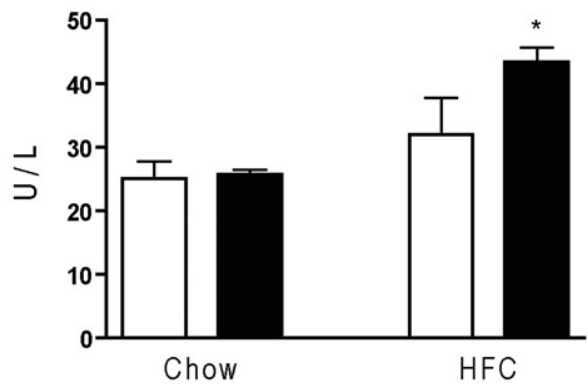

C

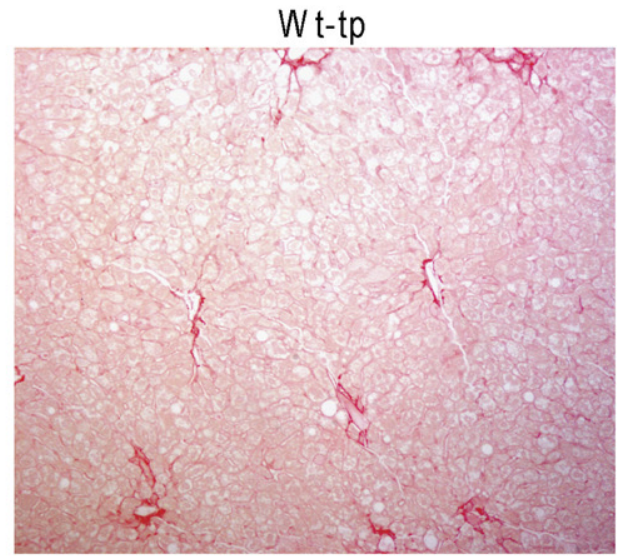

Tgf $-\beta$

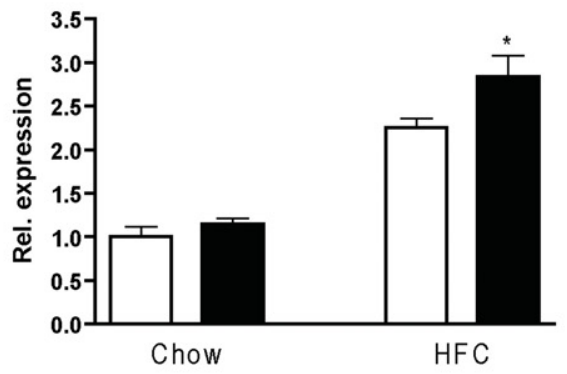

Mmp-9

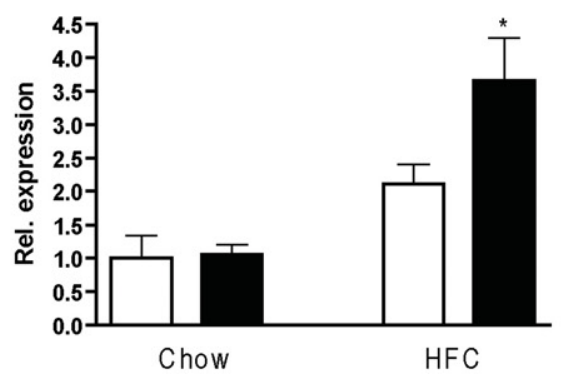

B
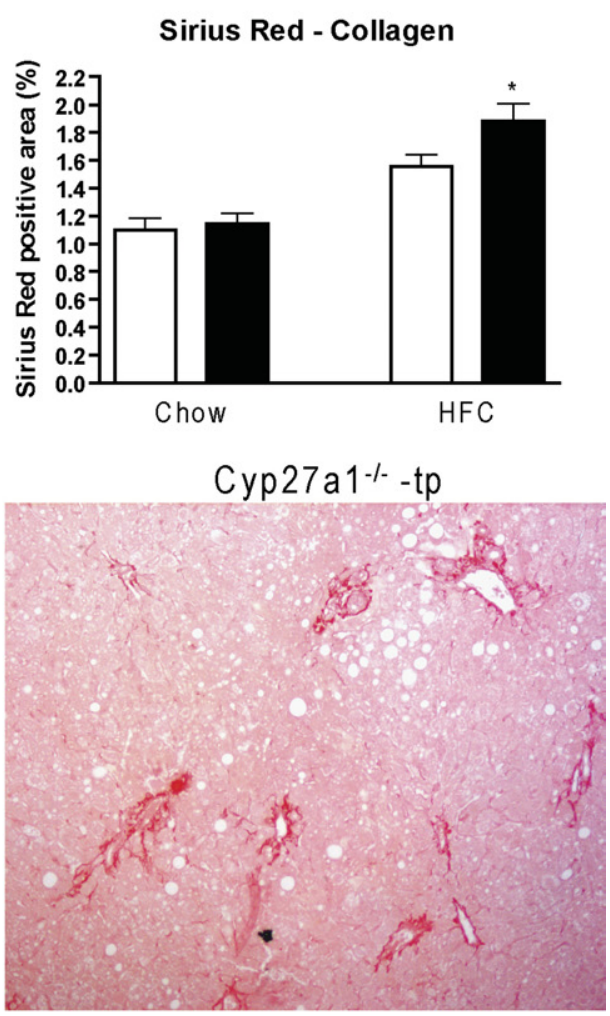

Col1a1

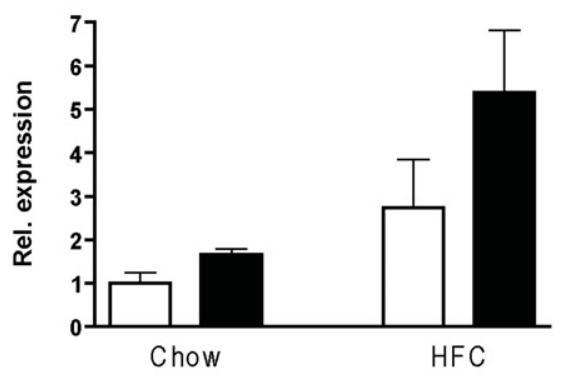

Pai-1

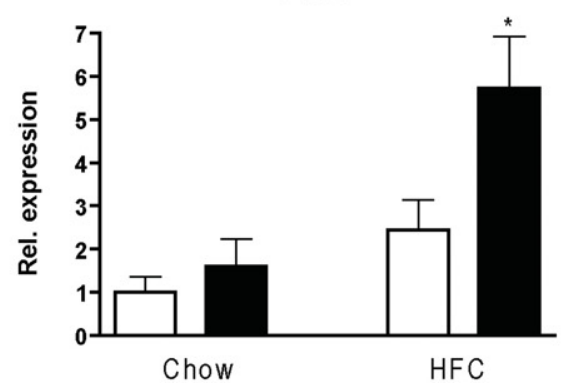

Figure 3. Liver damage and hepatic fibrosis in Wt-tp and Cyp27a1 ${ }^{-/-}$-tp mice. (A) Plasma alanine aminotransferase $(A L T)$ levels. (B) Quantification of Sirius Red staining after HFC diet. Livers were quantified by percentage of collagen present. (C) Representative pictures of Sirius Red staining (original magnification, 100 X) of Wt-tp and Cyp27a1-/--tp mice on HFC diet. $(D)$ Hepatic gene expression of Tgf- $\beta$, Col1a1, Mmp-9, and Pai-1. Gene expression data are shown relative to Wt-tp mice on chow diet. *Indicates $P<.05$. trol vehicle for 3 weeks and received either chow or HFC diet during this period. An extra group on the HFC diet received a control injection for 2 weeks, followed by $27 \mathrm{HC}$ injection in the last week. Plasma and liver 27HC levels increased significantly upon $27 \mathrm{HC}$ administration $(P<$ $.0001)$, whereas HFC diet caused a reduction in hepatic $27 \mathrm{HC} /$ cholesterol levels compared with chow (control chow vs HFC diet: $P<.0001 ; 27 \mathrm{HC}$ chow vs HFC diet: $P<.0001$ ) (Table 2). After 3 weeks of HFC diet, body weights did not differ significantly (data not shown), and equal levels of steatosis were observed in the different groups, as confirmed by Oil Red O staining (Supplementary Figure 5). Although hepatic TG levels were similar, hepatic cholesterol levels were significantly lower in the 
Table 2. Liver and Plasma Lipid Levels: Control- and 27HC-Injected Mice

\begin{tabular}{|c|c|c|c|c|c|}
\hline & \multicolumn{2}{|c|}{ Chow } & \multicolumn{3}{|c|}{ HFC } \\
\hline & Control & $27 \mathrm{HC}$ & Control & $27 \mathrm{HC}$ & $\begin{array}{c}2 \text { weeks Control }+1 \text { week } \\
27 \mathrm{HC}\end{array}$ \\
\hline \multicolumn{6}{|l|}{ Liver } \\
\hline $\mathrm{TG}(\mu \mathrm{g} T G / \mu g$ Prot) & $0.29( \pm 0.084)$ & $0.28( \pm 0.11)$ & $0.64( \pm 0.14)$ & $0.64( \pm 0.13)$ & $0.63( \pm 0.15)$ \\
\hline Chol ( $\mu g$ Chol/ $\mu g$ Prot) & $0.091( \pm 0.0086)$ & $0.088( \pm 0.0071)$ & $0.54( \pm 0.092)$ & $0.41( \pm 0.060)^{a}$ & $0.44( \pm 0.040)^{a}$ \\
\hline $27 \mathrm{HC} / \mathrm{Chol}$ & $0.36( \pm 0.067)$ & $7.73( \pm 1.55)^{b}$ & $0.10( \pm 0.014)$ & $1.70( \pm 0.39)^{b}$ & $0.96( \pm 0.16)^{b}$ \\
\hline \multicolumn{6}{|l|}{ Plasma } \\
\hline $\mathrm{TG}(\mathrm{mmol} / \mathrm{L})$ & $0.93( \pm 0.24)$ & $1.23( \pm 0.32)$ & $4.72( \pm 2.18)$ & $3.80( \pm 2.57)$ & $5.25( \pm 2.36)$ \\
\hline Chol $(\mathrm{mmol} / \mathrm{L})$ & $8.28( \pm 0.19)$ & $7.31( \pm 0.16)$ & $42.02( \pm 2.39)$ & $29.74( \pm 2.06)^{c}$ & $36.99( \pm 2.27)$ \\
\hline $27 \mathrm{HC} / \mathrm{Chol}\left(* 10^{-3}\right)$ & $0.43( \pm 0.034)$ & $19.15( \pm 7.33)^{b}$ & $0.60( \pm 0.026)$ & $6.65( \pm 1.07)^{b}$ & $6.20( \pm 0.64)^{b}$ \\
\hline
\end{tabular}

NOTE. Liver and plasma triglycerides, cholesterol, and 27HC levels after chow and HFC diet.

Chol, cholesterol; TG, triglycerides.

ap $<.01$.

${ }^{b} P<.001$.

${ }^{c} P<.05$.

27HC-treated mice on HFC diet than in control mice (27HC vs control: $P=.0023$; 2 weeks control +1 week $27 \mathrm{HC}$ vs control: $P=.008$ ) (Table 2). Plasma cholesterol levels were lower in 27HC-injected mice than in control mice on HFC diet $(P=.013)$. There were no differences between the groups on chow diet (Table 2).

\section{KCs Are Less Foamy and Have Less Lysosomal Cholesterol Storage After 27HC Administration}

After daily administration of $27 \mathrm{HC}$ to $\mathrm{Ldlr}^{-/-}$ mice, CD68 staining revealed a clear difference between 27HC and control-injected mice on HFC diet, with the $\mathrm{KCs}$ in $27 \mathrm{HC}$-injected mice having a less foamy appearance (Figure $4 A$ ). These data are in line with reduced gene expression of $C d 68$ (27HC vs control: $P=.031 ; 2$ weeks control +1 week $27 \mathrm{HC}$ vs control: $P=.050$ ) (Figure $4 B$ ). Electron microscopy of KCs from 27HC-injected mice demonstrated fewer lipids present inside lysosomes, indicated by acid phosphatase staining, and lower numbers of abnormal lipid structures resembling cholesterol precipitations (Figure $4 D$ ). In addition, whereas cholesterol crystals were present in the KCs of control injected mice upon HFC diet, they were not detected in KCs of 27HC-injected mice. The activity of the lysosomal enzyme cathepsin $\mathrm{D}$ in the livers of 27HC-injected mice was also lower than in control mice (27HC vs control: $P=.025$ ) (Figure $4 C$ ). Together, these data indicate that $27 \mathrm{HC}$ plays an important role in cellular cholesterol distribution.

\section{Increased LXR Expression in Kupffer Cells, but Not in Total Liver, Upon 27HC Administration}

To investigate the role of $27 \mathrm{HC}$ as physiologic LXR ligand, gene expression of $L x r$ and its downstream target genes Srebp-1c, $A b c a 1$, and $A b c g 1$ were analyzed in total liver and isolated $\mathrm{KCs}$ upon $27 \mathrm{HC}$ administration. The expression in total liver of $L x r-\alpha$ (27HC vs control: $P=$ .040; 2 weeks control +1 week $27 \mathrm{HC}$ vs control: $P=$ $.0083)$, together with the target genes Srebp-1c (27HC vs control: $P=.050$ ), Abca1 (27HC vs control: $P=.034 ; 2$ weeks control +1 week $27 \mathrm{HC}$ vs control: $P=.041)$, and Abcg1 (27HC vs control: $P=.021 ; 2$ weeks control +1 week $27 \mathrm{HC}$ vs control: $P=.018$ ) was lower upon $27 \mathrm{HC}$ administration than in control mice after HFC feeding (Supplementary Figure 6A). In isolated KCs, expression of Lxr- $\beta$ (27HC vs control: $P=.040)$, Srebp-1c (27HC vs control: $P=.038$ ), and $A b c a 1$ (27HC vs control: $P=.044$; 2 weeks control +1 week $27 \mathrm{HC}$ vs control: $P=.025)$ was higher upon $27 \mathrm{HC}$ administration than in control mice (Supplementary Figure 6B). These data suggest that the agonistic effect of 27HC on LXR in KCs is not dominant in all liver cells but is restricted to KCs.

\section{Hepatic Inflammation Is Reduced Upon 27HC Treatment}

Injections with $27 \mathrm{HC}$ reduced the number of infiltrating macrophages $(27 \mathrm{HC}$ vs control: $P=.0051 ; 2$ weeks control +1 week $27 \mathrm{HC}$ vs control: $P=.0097)$, neutrophils (27HC vs control: $P=.021$ ), and T cells (for both $27 \mathrm{HC}$ vs control and 2 weeks control +1 week 27HC vs control: $P<.0001$ ) in mice fed HFC diet (Figure $5 A$ and $B$ ), demonstrating the anti-inflammatory properties of 27HC. In addition, gene expression of $\operatorname{Tnf}(27 \mathrm{HC}$ vs control: $P=.030), M c p-1$ (27HC vs control: $P=.0027 ; 2$ weeks control +1 week $27 \mathrm{HC}$ vs control: $P=.029$ ), and Il-1 $\beta$ (27HC vs control: $P=.050)$ was lower in $27 \mathrm{HC}$ injected mice than in controls on HFC diet (Figure 5C). KCs isolated from 27HC-injected mice on HFC diet also had a lower expression of $\operatorname{Tnf}(27 \mathrm{HC}$ vs control: $P=.038$; 2 weeks control +1 week $27 \mathrm{HC}$ vs control: $P=.046$ ), Mcp-1 (27HC vs control: $P=.050 ; 2$ weeks control +1 week $27 \mathrm{HC}$ vs control: $P=.038)$, and $\mathrm{Il}-1 \beta$ (27HC vs control: $P=.021 ; 2$ weeks control +1 week $27 \mathrm{HC}$ vs control: $P=.012$ ) (Supplementary Figure 7), also demonstrating the effect of $27 \mathrm{HC}$ on KCs. Furthermore, expression of these inflammatory genes in isolated $\mathrm{KCs}$ is more than 10-fold higher compared with total livers, demon- 
A

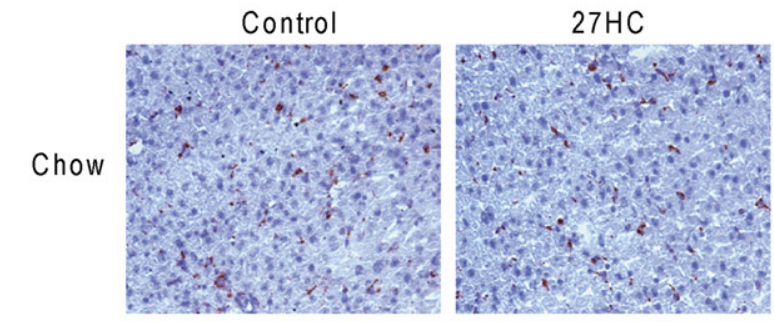

HFC

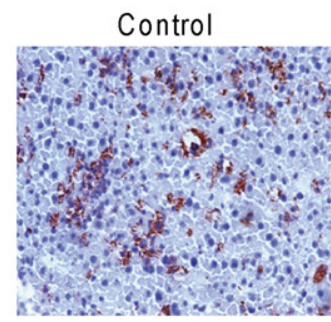

$27 \mathrm{HC}$

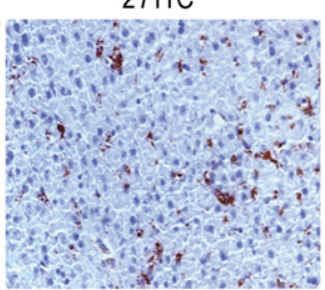

2w Control + 1w 27HC

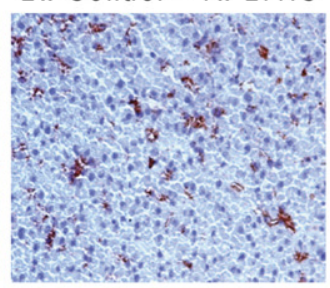

B

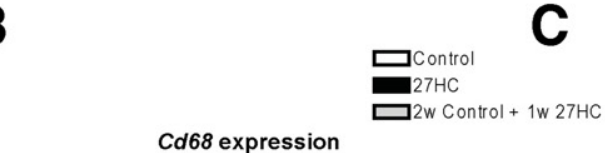

D
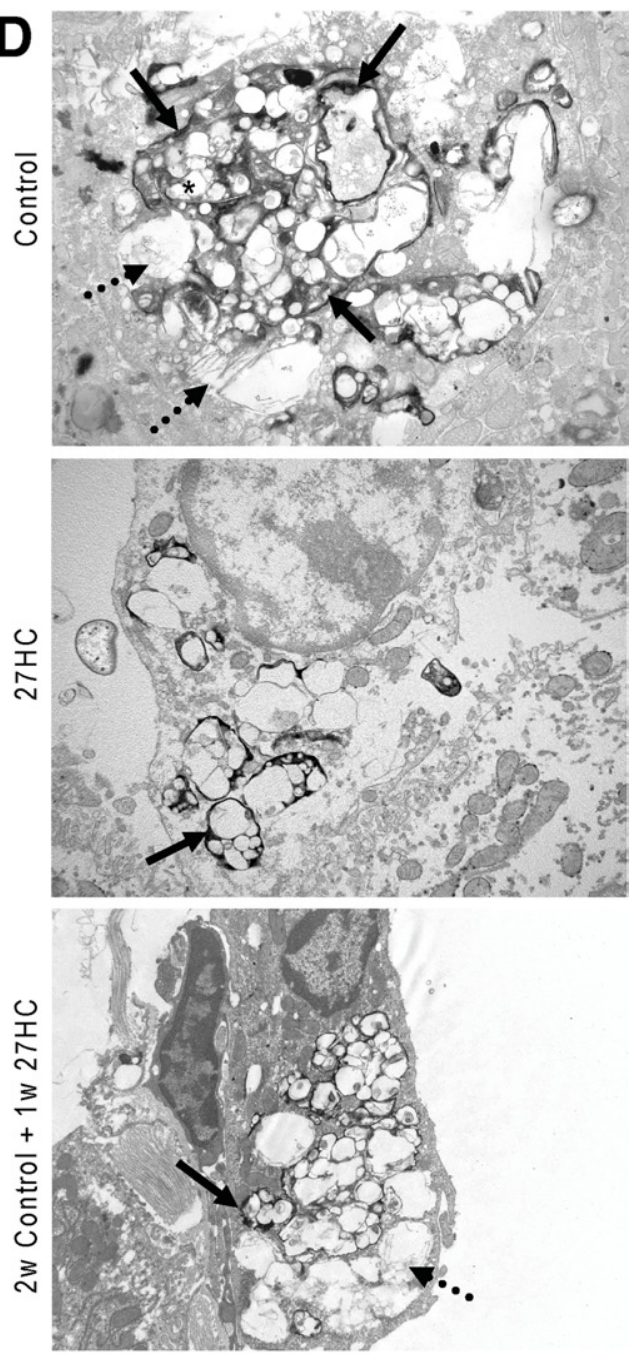

Figure 4. Foamy Kupffer cells, electron microscopy, and Cathepsin D activity in control- and 27HC-injected mice. (A) Representative pictures of CD68 staining (original magnification, 200X) after 3 weeks of chow or HFC diet. (B) Gene expression of the macrophage marker Cd68. (C) Hepatic activity of the lysosomal enzyme Cathepsin D. (D) Representative electron microscopy pictures of KCs. Lysosomes are indicated in black by acid phosphatase staining (solid arrows), abnormal lipid structures resembling cholesterol precipitations are indicated by the broken arrows, and cholesterol crystals are indicated by asterisks. ${ }^{*}$ Indicates $P<.05$ and ${ }^{\star *} P<.01$.

strating that the inflammatory response in the liver is mainly derived from KCs.

No differences were observed in plasma ALT levels or hepatic fibrosis after HFC diet (data not shown), which is probably related to the short duration of the HFC diet. In addition, the level of oxidative stress was not affected upon 27HC administration (Supplementary Figure 8). In conclusion, 27HC plays an important role during hepatic inflammation.

\section{HC Is Not Elevated in NASH Patients}

To test the potential clinical utility of $27 \mathrm{HC}$ to NASH patients, we measured plasma $27 \mathrm{HC} /$ cholesterol levels in 69 obese subjects (average body mass index = 34.2), classified into normal, steatosis, or NASH according to the criteria of Kleiner, as described previously. ${ }^{15-18}$ Male subjects had 15\% higher 27HC levels than females $(P=$ .021 ), independent of plasma cholesterol (Supplementary Figure 9A). Although a positive correlation between plasma cholesterol and 27HC levels was observed (males: $r=0.22, P<.0001$; females: $r=0.58, P<.0001)$ (Supplementary Figure $9 B$ and $C$ ), there was no difference in 27HC levels in NASH patients compared with subjects with a healthy liver or steatosis (data not shown).

\section{Discussion}

Despite considerable efforts to unravel them, the mechanisms underlying the causes of inflammation in NASH are largely unknown, thereby limiting the treatment options for NASH. We have previously shown dietary cholesterol to be an important factor in the development of hepatic inflammation in mice. ${ }^{10}$ Here, we show that lysosomal cholesterol accumulation inside KCs may be a major trigger for the development of hepatic inflammation. This study also provides the first in vivo evidence that $27 \mathrm{HC}$ has an impact on intracellular cholesterol distribution in KCs. Finally, the current study points to the potential of $27 \mathrm{HC}$ as a novel treatment for NASH. 
A $\square_{2 \mathrm{WC} \text { Control + 1w 27HC) }}^{\text {Control }}$

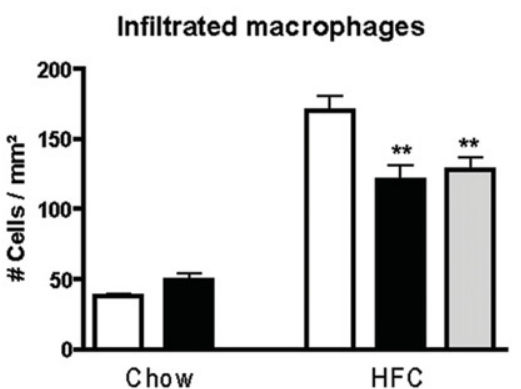

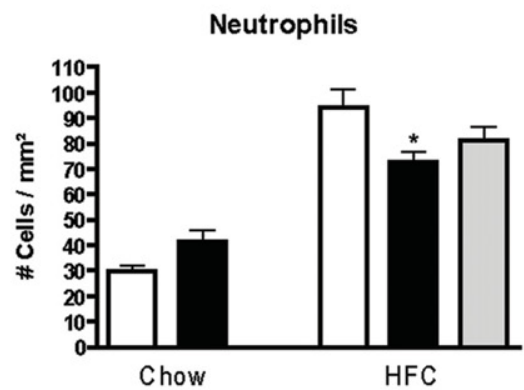

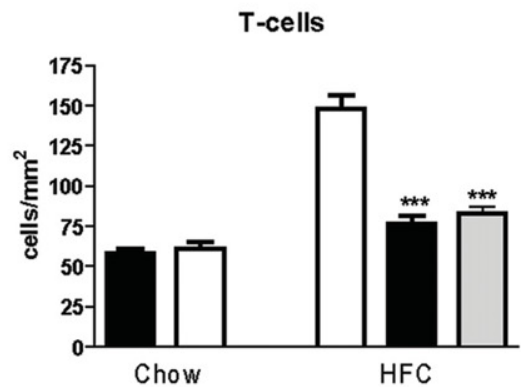

B
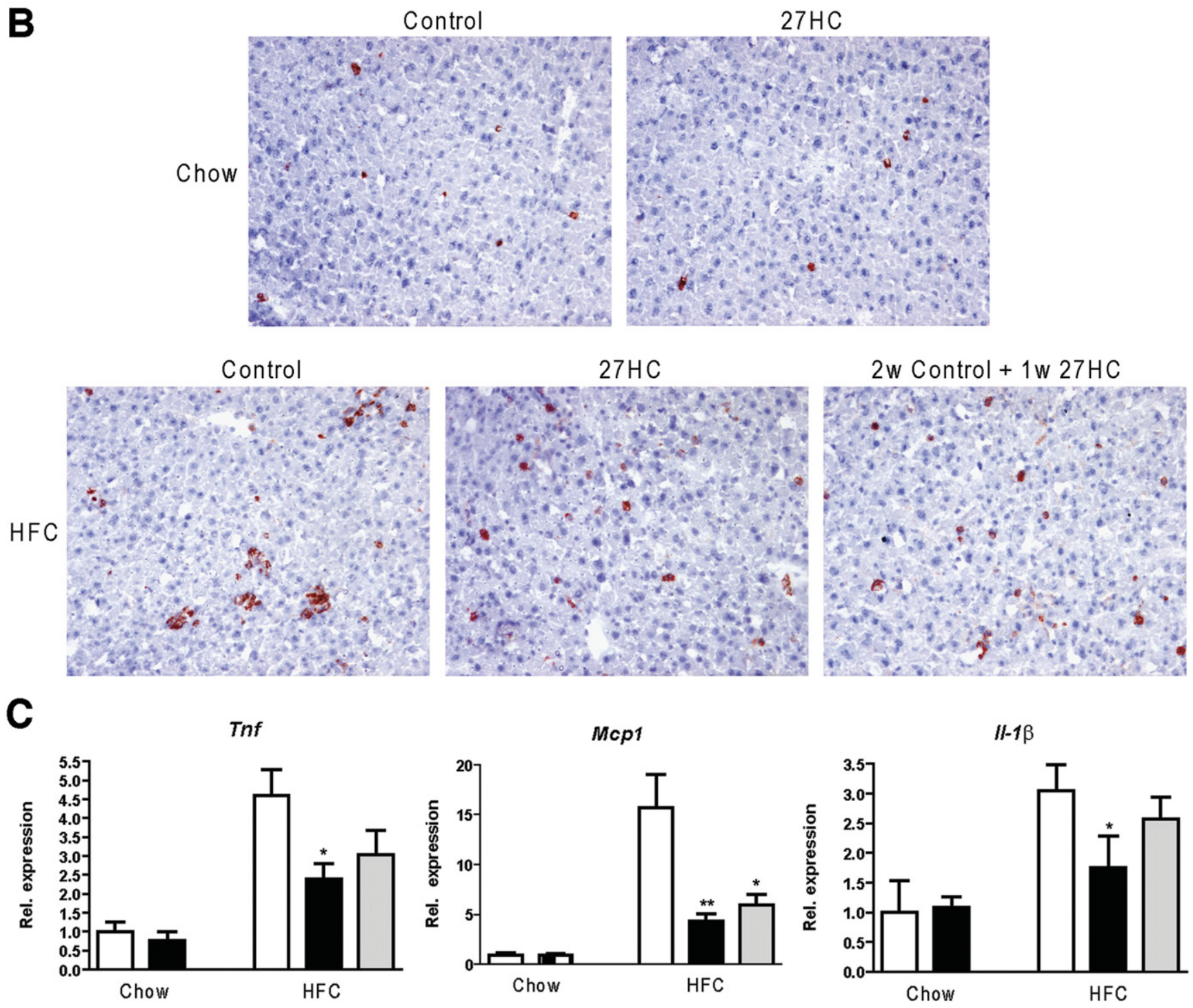

Figure 5. Parameters of hepatic inflammation in control- and 27HC-injected mice. (A) Liver sections were stained for infiltrating macrophages, neutrophils, and T cells and the positive cells counted. (B) Representative pictures of Mac-1 staining (original magnification, $200 \times$ ) after 3 weeks of HFC diet. (C) Gene expression analysis of Tnf, Mcp-1, and II-1 $\beta$. Data are shown relative to control mice on chow diet. ${ }^{*}$ Indicates $P<.05$, ${ }^{* \star} P<.01$, and ${ }^{\star \star *} P<.001$

\section{Association Between Lysosomal Cholesterol Accumulation and Inflammation in NASH}

Whereas the intracellular cholesterol distribution specifically in KCs has not yet been shown to affect he- patic inflammation, several lines of evidence have indicated a general association between lysosomal cholesterol accumulation and inflammation. One factor important in preventing such cholesterol accumulation in lysosomes is 
the enzyme lysosomal acid lipase, essential for the hydrolysis of triglycerides and cholesteryl esters in lysosomes. A deficiency in this enzyme leads to lysosomal cholesterol accumulation and inflammation in multiple organs, phenomena similar to our observations in hyperlipidemic mice $\left(\mathrm{Ldlr}^{-/-}\right)$. Likewise, patients with mutations in NPC 1 and 2, proteins that facilitate the movement of cholesterol from the lysosomes to the cytoplasmic compartment, commonly have a very poorly functioning liver, and approximately $10 \%$ of these patients die of liver failure. ${ }^{19}$ Whereas lysosomes have been assigned a central role in many processes involving tissue injury and inflammation, ${ }^{20}$ the association between lysosomal cholesterol storage and inflammation in relation to the metabolic syndrome is not fully understood. In the present study, we show that increased lysosomal cholesterol storage leads to increased hepatic inflammation. These data are in line with the finding in $\mathrm{Ldll}^{-/-}$mice on an HFC diet that a decrease in lysosomal cholesterol storage by means of exogenous lysosomal acid lipase administration leads to significant reductions in hepatic inflammation, steatosis, and atherosclerotic lesion size. ${ }^{21}$

By reducing lysosomal cholesterol storage and damage, $27 \mathrm{HC}$ can indirectly reduce inflammation by several mechanisms. Because we observed decreased hepatic cathepsin D activity and reduced lysosomal cholesterol storage upon 27HC treatment, lysosomal instability can also be a possible explanation for the inflammatory response observed in our experiments because the stability and integrity of lysosomal membranes are important to maintain normal levels of lysosomal enzymes in tissues and body fluids. ${ }^{22}$ Furthermore, $27 \mathrm{HC}$ administration resulted in reduced formation of cholesterol crystals inside KCs. Because these crystals can induce rupture of phagolysosomes leading to the release of the proteolytic lysosomal contents into the cytosol and thereby activation of the NOD-like receptor protein 3 (NLRP3) inflammasome, treatment with $27 \mathrm{HC}$ can prevent the proinflammatory effects of inflammasome activation. ${ }^{23}$ Therefore, the reduced activity of cathepsin $\mathrm{D}$ and the absence of cholesterol crystals inside $\mathrm{KCs}$ upon $27 \mathrm{HC}$ administration can be a possible explanation for the beneficial effects of $27 \mathrm{HC}$ on lysosomal cholesterol storage and inflammatory gene expression. Because KCs are a primary source of inflammatory cytokines in the liver ${ }^{24}$ and can indirectly influence the phenotype of neighboring hepatocytes and other immune cells via the production of inflammatory cytokines and cross talking with other liver cell types, ${ }^{25}$ it is very likely that $27 \mathrm{HC}$ is also contributing (indirectly) to the inflammatory properties on hepatocytes.

\section{HC Has the Potential to Lower Plasma Cholesterol Levels}

Our study makes use of hematopoietic cells from knockout mice lacking the Cyp27a1 gene. In humans, CYP27A1 deficiency leads to cerebrotendinous xanthomatosis (CTX), a disease associated with the accumulation of cholesterol and cholestanol in many organs. However,
Cyp27a1 $1^{-1-}$ mice lack the classic symptoms of CTX. ${ }^{26}$ They have either normal plasma lipid levels, similar to CTX patients, ${ }^{27}$ or are hyperlipidemic. ${ }^{28}$ These findings are supported by our current data: although on normal diet, plasma cholesterol levels were similar in Cyp27a1 ${ }^{-/-}$-tp mice and Wt-tp mice, as well as in both $27 \mathrm{HC}$ and controlinjected mice, after an HFC diet, plasma cholesterol levels were dramatically lower in Cyp27a1-/- $t \mathrm{p}$ and $27 \mathrm{HC}$-injected mice than in the control groups. Despite the reduced foamy appearance of KCs in Cyp27a1 $11^{-/-}$-tp mice, hepatic inflammation was still higher than in control

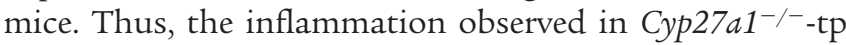
occurs despite the reduction in cholesterol levels. In keeping with these observations, Zhang et al demonstrated that, in $\mathrm{Npc1}^{-/-}$-tp $\mathrm{Ldlr}^{-/-}$mice, serum cholesterol and TG levels are reduced after an HFC diet in the presence of increased aortic atherosclerosis. ${ }^{29}$ Altogether, the data suggest that $27 \mathrm{HC}$ can affect cholesterol metabolism in mice fed an HFC diet.

By measuring the expression of $27 \mathrm{HC} /$ cholesterol in plasma of patients with a wide variety of fatty liver disease, no differences in $27 \mathrm{HC}$ levels in NASH patients compared with subjects with a healthy liver or steatosis were observed. The absence of correlation between $27 \mathrm{HC}$ levels to severity of NAFLD is likely related to the tight regulation of $27 \mathrm{HC}$ synthesis by the mitochondria, which prevents a decrease in 27HC levels. ${ }^{30}$ Nevertheless, in patients with CTX, the extremely low $27 \mathrm{HC}$ levels are correlated with increased liver damage. ${ }^{31}$ Relevantly, a study using chimeric $\mathrm{Npc1}^{-/-}$mice, where $27 \mathrm{HC}$ synthesis by macrophages is decreased, reveals an association between the lowered $27 \mathrm{HC}$ levels in macrophages and elevated cholesterol oxidation products and oxidative stress in macrophages and plasma. ${ }^{29}$ Altogether, these data suggest that, although plasma $27 \mathrm{HC}$ levels cannot be used as a marker for NASH, elevating 27HC levels in NASH patients might be beneficial. Therefore, further experiments are needed to test the efficiency of $27 \mathrm{HC}$ in humans.

\section{Potential of 27HC to Reduce Hepatic Inflammation}

Treatment options for NASH are currently limited because of lack of understanding regarding the mechanisms that triggers hepatic inflammation in these patients. In the present study, we have shown for the first time that 27HC potentially reduces hepatic inflammation in $\mathrm{Ldlr}^{-/-}$mice, apparently associated with reduced lysosomal cholesterol storage inside KCs. In line with our findings, lysosomal cholesterol accumulation in NiemannPick disease type $\mathrm{C}$ is associated with considerably reduced $27 \mathrm{HC}$ production in human $\mathrm{NPC1}^{-/-}$fibroblasts; incubation with $27 \mathrm{HC}$ dramatically reduces lysosomal cholesterol in these cells. ${ }^{7,8}$ One possible explanation for this phenomenon is that the added oxysterol somehow eliminates the excess cholesterol in the cytoplasm, and therefore cholesterol is transferred from lysosomes to the cytoplasm to maintain homeostasis. However, intriguing recent findings that $27 \mathrm{HC}$ binds to the $\mathrm{N}$-terminal lumi- 
nal loop of NPC1 also suggest a direct molecular link between oxysterols and NPC function. ${ }^{32}$ A further explanation involves the suggestion that $27 \mathrm{HC}$ is a physiologic LXR ligand, similar to other oxysterols. ${ }^{33}$ LXRs, together with other members of the nuclear receptor superfamily, contribute to cellular cholesterol homeostasis by regulating genes that control the storage, transport, and catabolism of cholesterol. ${ }^{34}$ However, it is also demonstrated that oxysterols can function as antagonistic ligands for LXR. ${ }^{35}$ 27HC is found in large amounts in foam cells of atherosclerotic plaques, where it is thought to eliminate excess cholesterol by stimulating reverse cholesterol transport via LXR and inhibiting cholesterol synthesis and uptake via sterol regulatory element binding protein. ${ }^{36}$ Therefore, a possible mechanism for the reduced expression of inflammatory genes upon $27 \mathrm{HC}$ administration can be related to LXR activation. In the present study, we observed that the agonistic effects of $27 \mathrm{HC}$ were restricted to KCs and were mainly LXR- $\beta$ dependent, whereas $27 \mathrm{HC}$ acted as an antagonistic ligand of LXR in total liver and was mainly LXR- $\alpha$ driven. Therefore, the agonistic as well as antagonistic actions of 27HC on LXR are cell specific, indicating that $27 \mathrm{HC}$ functions as an endogenous selective LXR modulator. Taken together, these studies provide a possible explanation for the controversial data in literature regarding the role of 27HC in cholesterol metabolism.

Oxysterols such as $27 \mathrm{HC}$ are therefore already considered to be potential candidates for the reduction of cellular toxicity. Although some in vitro studies have demonstrated that oxysterols may have some cytotoxic, oxidative, and/or inflammatory effects, ${ }^{37}$ most data are highly controversial, and more appropriate in vivo and in vitro models of investigation as well as clinical investigations are required to improve knowledge of oxysterol activities. The current study demonstrates that $27 \mathrm{HC}$ administration can reduce hepatic inflammation and modulate intracellular cholesterol distribution inside KCs. The potential of $27 \mathrm{HC}$ as a novel tool for the treatment of NASH should therefore be tested.

In conclusion, in the present study, lysosomal cholesterol accumulation in KCs was associated with increased hepatic inflammation. These data support a mechanism by which lysosomal cholesterol accumulation can act as a trigger for hepatic inflammation and point to the potential of using $27 \mathrm{HC}$ as a novel treatment for NASH.

\section{Supplementary Material}

Note: To access the supplementary material accompanying this article, visit the online version of Gastroenterology at www.gastrojournal.org, and at http:// dx.doi.org/10.1053/j.gastro.2012.09.062.

\section{References}

1. Angulo P. Nonalcoholic fatty liver disease. N Engl J Med 2002; 346:1221-1231.

2. Bieghs V, Wouters K, van Gorp PJ, et al. Role of scavenger receptor $A$ and $C D 36$ in diet-induced nonalcoholic steatohepatitis in hyperlipidemic mice. Gastroenterology 2010;138:24772486,e1-3.
3. Bieghs V, Verheyen F, van Gorp PJ, et al. Internalization of modified lipids by CD36 and SR-A leads to hepatic inflammation and lysosomal cholesterol storage in Kupffer cells. PLoS One 2012; $7: \mathrm{e} 34378$.

4. Bieghs V, van Gorp PJ, Walenbergh SM, et al. Specific immunization strategies against oxidized low-density lipoprotein: A novel way to reduce nonalcoholic steatohepatitis in mice. Hepatology 2012;56:894-903.

5. Brown MS, Goldstein JL. Lipoprotein metabolism in the macrophage: implications for cholesterol deposition in atherosclerosis. Annu Rev Biochem 1983;52:223-261.

6. Griffin EE, Ullery JC, Cox BE, et al. Aggregated LDL and lipid dispersions induce lysosomal cholesteryl ester accumulation in macrophage foam cells. J Lipid Res 2005;46:2052-2060.

7. Lange $\mathrm{Y}, \mathrm{Ye} J$, Rigney M, et al. Cholesterol movement in NiemannPick type $C$ cells and in cells treated with amphiphiles. J Biol Chem 2000;275:17468-17475.

8. Frolov A, Zielinski SE, Crowley JR, et al. NPC1 and NPC2 regulate cellular cholesterol homeostasis through generation of low density lipoprotein cholesterol-derived oxysterols. J Biol Chem 2003;278: 25517-25525.

9. De Caprio J, Yun J, Javitt NB. Bile acid and sterol solubilization in 2-hydroxypropyl- $\beta$-cyclodextrin. J Lipid Res 1992;33:441-3.

10. Wouters K, van Gorp PJ, Bieghs V, et al. Dietary cholesterol, rather than liver steatosis, leads to hepatic inflammation in hyperlipidemic mouse models of nonalcoholic steatohepatitis. Hepatology 2008;48:474-486.

11. Wisse E, Braet F, Duimel H, et al. Fixation methods for electron microscopy of human and other liver. World J Gastroenterol 2010; 16:2851-2866.

12. Shiri-Sverdlov R, Wouters K, van Gorp PJ, et al. Early diet-induced non-alcoholic steatohepatitis in APOE2 knock-in mice and its prevention by fibrates. J Hepatol 2006;44:732-741.

13. Diehl AM, Li ZP, Lin HZ, et al. Cytokines and the pathogenesis of non-alcoholic steatohepatitis. Gut 2005;54:303-306.

14. Moshage $\mathrm{H}$. Cytokines and the hepatic acute phase response. J Pathol 1997;181:257-266.

15. Kalhan SC, Edmison J, Marczewski S, et al. Methionine and protein metabolism in non-alcoholic steatohepatitis: evidence for lower rate of transmethylation of methionine. Clin Sci (Lond) 2011;121:179-189.

16. Kasumov T, Edmison JM, Dasarathy $\mathrm{S}$, et al. Plasma levels of asymmetric dimethylarginine in patients with biopsy-proven nonalcoholic fatty liver disease. Metabolism 2011;60:776-781.

17. Dasarathy S, Kasumov T, Edmison JM, et al. Glycine and urea kinetics in nonalcoholic steatohepatitis in human: effect of intralipid infusion. Am J Physiol Gastrointest Liver Physiol 2009;297: G567-G575.

18. Kalhan SC, Guo L, Edmison J, et al. Plasma metabolomic profile in nonalcoholic fatty liver disease. Metabolism 2011;60:404-413.

19. Vanier MT, Millat G. Niemann-Pick disease type C. Clin Genet 2003;64:269-281.

20. Weissmann G. The role of lysosomes in inflammation and disease. Annu Rev Med 1967;18:97-112.

21. Du H, Schiavi S, Wan N, et al. Reduction of atherosclerotic plaques by lysosomal acid lipase supplementation. Arterioscler Thromb Vasc Biol 2004;24:147-154.

22. George J. Elevated serum $\beta$-glucuronidase reflects hepatic lysosomal fragility following toxic liver injury in rats. Biochem Cell Biol 2008;86:235-243.

23. Hornung V, Bauernfeind $F$, Halle $A$, et al. Silica crystals and aluminum salts activate the NALP3 inflammasome through phagosomal destabilization. Nat Immunol 2008;9:847-856.

24. Baffy G. Kupffer cells in non-alcoholic fatty liver disease: the emerging view. J Hepatol 2009;51:212-223.

25. Racanelli V, Rehermann B. The liver as an immunological organ. Hepatology 2006;43:S54-S62.

26. Rosen H, Reshef A, Maeda N, et al. Markedly reduced bile acid synthesis but maintained levels of cholesterol and vitamin $D$ 
metabolites in mice with disrupted sterol 27-hydroxylase gene. J Biol Chem 1998;273:14805-14812.

27. Dubrac S, Lear SR, Ananthanarayanan M, et al. Role of CYP27A in cholesterol and bile acid metabolism. J Lipid Res 2005;46:76-85.

28. Repa JJ, Lund EG, Horton JD, et al. Disruption of the sterol 27-hydroxylase gene in mice results in hepatomegaly and hypertriglyceridemia. Reversal by cholic acid feeding. J Biol Chem 2000; 275:39685-39692.

29. Zhang JR, Coleman T, Langmade SJ, et al. Niemann-Pick C1 protects against atherosclerosis in mice via regulation of macrophage intracellular cholesterol trafficking. J Clin Invest 2008;118: 2281-2290.

30. Lange Y, Ory DS, Ye J, et al. Effectors of rapid homeostatic responses of endoplasmic reticulum cholesterol and 3-hydroxy-3-methylglutaryl-CoA reductase. J Biol Chem 2008;283:1445-1455.

31. Boehme DH, Sobel HJ, Marquet E, et al. Liver in cerebrotendinous xanthomatosis (CTX): a histochemical and EM study of four cases. Pathol Res Pract 1980;170:192-201.

32. Infante RE, Abi-Mosleh L, Radhakrishnan A, et al. Purified NPC1 protein. I. Binding of cholesterol and oxysterols to a 1278-amino acid membrane protein. J Biol Chem 2008;283:1052-1063.

33. Chen W, Chen G, Head DL, et al. Enzymatic reduction of oxysterols impairs LXR signaling in cultured cells and the livers of mice. Cell Metab 2007;5:73-79.

34. Ory DS. Nuclear receptor signaling in the control of cholesterol homeostasis: have the orphans found a home? Circ Res 2004; 95:660-670.
35. Song C, Hiipakka RA, Liao S. Auto-oxidized cholesterol sulfates are antagonistic ligands of liver $X$ receptors: implications for the development and treatment of atherosclerosis. Steroids 2001; 66:473-479.

36. Gill S, Chow R, Brown AJ. Sterol regulators of cholesterol homeostasis and beyond: the oxysterol hypothesis revisited and revised. Prog Lipid Res 2008;47:391-404.

37. Vejux A, Malvitte L, Lizard G. Side effects of oxysterols: cytotoxicity, oxidation, inflammation, and phospholipidosis. Braz J Med Biol Res 2008;41:545-556.

Received March 22, 2012. Accepted September 19, 2012.

\section{Reprint requests}

Address requests for reprints to: Ronit Shiri-Sverdlov, PhD, Department of Molecular Genetics, Maastricht University, PO Box 616, 6200MD Maastricht, The Netherlands. e-mail: r.sverdlov@maastrichtuniversity.nl; fax: (31) 43-388-4574.

\section{Conflicts of interest}

The authors disclose no conflicts.

\section{Funding}

Veni: 916.76 .070 (2006/00496/MW), Maag Lever Darm Stichting (MLDS) (WO 08-16 and 11-35); and Vidi: 016.126.327. 


\section{Supplementary Materials and Methods}

\section{Subjects}

Sixty-nine obese patients (41 females, 28 males) were recruited from the metabolic clinics at MetroHealth Medical Center and at the Cleveland Clinic. Non-alcoholic steatohepatitis was confirmed by liver biopsy according to the criteria of Kleiner et al. ${ }^{1}$ All subjects in the present study were evaluated by the investigators and were abstinent from alcohol for at least 6 months. Their possible remote consumption of alcohol was less than that suggested to cause liver injury. The study protocol was approved by the institutional review boards at Cleveland Clinic and MetroHealth Medical Center. Written informed consent was obtained from all subjects after fully explaining the procedure.

\section{Kupffer Cell Isolation}

Small pieces of liver from all mice were pooled per experimental group and digested in digestion buffer containing Liberase TM $(33.3 \mu \mathrm{g} / \mathrm{mL})$ and $0.002 \%$ DNaseI for 20 minutes at $37^{\circ} \mathrm{C}$. Tissue was further disrupted by pushing it through a $100-\mu \mathrm{m}$ cell strainer using wash buffer (phosphate-buffered saline, 1\% fetal calf serum, 2.5 $\mathrm{mmol} / \mathrm{L}$ EDTA), and then the cells were pelleted at 1500 $\mathrm{rpm}, 10$ minutes, at $4^{\circ} \mathrm{C}$. After resuspension of cells in wash buffer, hepatocytes were removed by 1 low-spin centrifugation step at $300 \mathrm{rpm}, 3$ minutes. Supernatant was collected and centrifuged, and red blood cells were lysed. Next, Kupffer cells were selected using magnetic beads coated with a macrophage-specific monoclonal antibody (F4/80). After incubation of cells with these F4/ 80-Allophycocyanin $\left(1 \mu \mathrm{L} / 80 \times 10^{6}\right.$ cells) (Biolegend, Breda, the Netherlands) for 20 minutes at $4^{\circ} \mathrm{C}$, cells were washed and anti-APC microBeads $\left(200 \mu \mathrm{L} / 100 \times 10^{6}\right.$ cells) (Miltenyi Biotec, Auburn, CA) were added, followed by incubation in the dark for 20 minutes at $4^{\circ} \mathrm{C}$. After washing, samples were run into LS columns, put on a Quadro MACS magnet (Miltenyi Biotec), and rinsed with wash buffer. Positively selected cells were flushed using wash buffer and collected for further analysis.

\section{Cathepsin D Activity Assay}

Cathepsin D activity was measured using the cathepsin D activity assay kit (MBL International, Woburn, MA) according to the manufacturer's protocol. In summary, $50 \mu \mathrm{g}$ of liver homogenate was lysed in cathepsin D lysis buffer on ice for 10 minutes. Following centrifugation for 5 minutes at top speed, $5 \mu \mathrm{L}$ of clear cell lysate was transferred to a well of a 96-well plate, and the total volume was made up to $50 \mu \mathrm{L}$ with cathepsin $\mathrm{D}$ cell lysis buffer. To each assay, $52 \mu \mathrm{L}$ of master mix (50 $\mu \mathrm{L}$ of CD Reaction Buffer and $2 \mu \mathrm{L}$ of CD Substrate) was added, and the plate was incubated at $37^{\circ} \mathrm{C}$ for 1 hour. Samples were then measured using a fluorescence plate reader with a 328-nm excitation filter and 460-nm emission filter. Cathepsin D activity is expressed by the relative fluorescence units.

\section{Malondialdehyde Assay}

The assay is based on the formation of a colored adduct of malondialdehyde-like breakdown products of lipids with 2-thiobarbituric acid (TBA) $)^{2,3}$ and is performed as recently described. ${ }^{4}$ In brief, liver tissue was added to $1 \mathrm{~mL}$ of reagent, containing $12 \mathrm{mmol} / \mathrm{L} \mathrm{TBA}, 0.32 \mathrm{~mol} / \mathrm{L} o$-phosphoric acid, $0.68 \mathrm{mmol} / \mathrm{L}$ butylated hydroxytoluene, and $0.01 \%$ EDTA, and the mixture was incubated for 1 hour at $100^{\circ} \mathrm{C}$ in a water bath. After cooling, the TBA product was extracted with $100 \mu \mathrm{L}$ of butanol. A portion $(30 \mu \mathrm{L})$ of the butanol layer was injected on to an high-performance liquid chromatography system (Agilent Technologies, Amstelveen, the Netherlands) equipped with a fluorescence detector, set at an excitation wavelength of $530 \mathrm{~nm}$ and emission wavelength of $560 \mathrm{~nm}$, and a Nucleosil C18 column $(150 \mathrm{~mm} \times$ $3.2 \mathrm{~mm}$; particle size, $5 \mu \mathrm{m}$; Supelco, Sigma-Aldrich, Zwijndrecht, the Netherlands). Samples were eluted with 35\% (vol/vol) methanol containing $0.05 \%$ trifluoric acid. A calibration curve was constructed using malondialdehyde bis(diethylacetal) as a standard.

\section{Antioxidant Capacity Assay}

The antioxidant capacity in liver was assayed using the method described by Fischer et al. ${ }^{5}$ Briefly, $950 \mu \mathrm{L}$ of $\mathrm{ABTS}^{\bullet+}$ radical solution was incubated for 1 minute at $37^{\circ} \mathrm{C}$; thereafter, $50 \mu \mathrm{L}$ of deproteinized liver was added. After incubation for 5 minutes, the absorption at $734 \mathrm{~nm}$ was measured. The resulting value is expressed as trolox equivalent antioxidant capacity. Because trolox equivalent antioxidant capacity is partly determined by the uric acid concentration, the raw data from this assay were corrected for the uric acid content of the sample.

\section{Statistical Analysis}

Data were analyzed using Graphpad Prism 4.0.3 software (National Institutes of Health, Bethesda, MD). Groups were compared using the unpaired $t$ test. The data were expressed as the mean and standard error of the mean and were considered significantly different at ${ }^{*} P<.05 ;{ }^{*} P<.01$, or ${ }^{*}{ }^{*} P<.001$.

\section{References}

1. Kleiner DE, Brunt EM, Van Natta M, et al. Design and validation of a histological scoring system for nonalcoholic fatty liver disease. Hepatology 2005;41:1313-1321.

2. Lepage G, Munoz G, Champagne J, et al. Preparative steps necessary for the accurate measurement of malondialdehyde by high-performance liquid chromatography. Anal Biochem 1991;197:277-283.

3. Guillen-Sans R, Guzman-Chozas M. The thiobarbituric acid (TBA) reaction in foods: a review. Crit Rev Food Sci Nutr 1998;38:315-330.

4. van de Poll MC, Dejong $\mathrm{CH}$, Fischer MA, et al. Decreased hepatosplanchnic antioxidant uptake during hepatic ischaemia/reperfusion in patients undergoing liver resection. Clin Sci (Lond) 2008;114:553-560.

5. Fischer MA, Gransier TJ, Beckers LM, et al. Determination of the antioxidant capacity in blood. Clin Chem Lab Med 2005;43:735740. 